\title{
Little Miss Why's learning journey
}

The more teaching that I do the more fascinated I become with the entire process of learning and reflection. During the course of studying for a Postgraduate Certificate in Medical Education I had cause to start to look critically at some educational literature surrounding how learners learn and the article that follows is a reflection of my own 'learning journey' with reference to the literature I discovered during my studies. ${ }^{1}$

As a young child my mother nicknamed me 'Little Miss Why' because I was never satisfied with a simple answer and was always seeking deeper knowledge. At primary school I was a keen participant, ${ }^{2}$ although I am aware now that behaviourism was obviously playing a part in my development as I responded to positive and negative reinforcement. ${ }^{3}$ At a preoperational level my education was always very learner-centred and I can remember finding it quite difficult to move into a primary school environment where I was unable to dictate any of my learning goals. I found the personal model ${ }^{4}$ was often favoured by teachers, which often created difficulties when the teacher could not accept that I might have different values or needs. I remember a particular incident in primary school where a teacher insisted that we should all have handwriting identical to hers and spent many days getting us to relearn the way we shaped our letters to be identical to hers in spite of the fact that at 10 years of age I had developed my own (legible and competent) handwriting.

At secondary school I became a very competitive learner. ${ }^{2}$ Many of my subjects were taught in mixed ability groups and I have to admit that I was rarely patient or accepting of other pupils who struggled to understand the subject matter. I found collaboration very difficult in my early secondary school years, partly, I think, because I found it difficult to understand the differences between sharing knowledge and cheating.

I found computer studies especially challenging. I could not understand binary and saw no relevance in what I was supposed to be learning. I was hopeless at art and was constantly filled with a sense of failure. Sadly the concept of self-efficacy ${ }^{5}$ was never explored in these subjects, I accept that I will probably never be able to draw but I think that had my computer studies teacher been clearer and better at providing 'guided practice with corrective feedback' I might have gained something from my lessons other than a sense of total failure.

Little Miss Why was still present - I struggled to engage with the surface approach to learning. ${ }^{6}$ I found Latin a challenge and clearly remember my teacher shouting repeatedly 'a gerund is a passive verbal adjective' over and over again totally unable to comprehend that fact that I had not understood this explanation the first time and no amount of shouting was going to help.

I was inspired by some excellent teachers who managed to focus on a syllabus while allowing some creativity and learner input. This was especially apparent during my English Literature A level where I was introduced to a facilitated small group learning environment. My gap year in Malaysia required a lot of self-directed learning. I worked in a children's home where few of the staff or children spoke English and I quickly picked up the local language. I was entirely self-directed and I learned quickly because it was so relevant to my life - my first foray into truly adult learning. ${ }^{?}$

Medical school was quite a shock. There seemed to be no set curriculum. Perhaps this was drawing on principles of constructivism, ${ }^{8}$ but । found it very challenging to prepare for examinations without any guidance on the subject matter. Most of the pre-clinical teaching was in a lecture format with 'expert' and 'formal authority' figures. I found it difficult at first to adapt to the change from small group learning. I began to develop an achieving approach to some of my learning, accepting that at times surface learning ${ }^{6}$ can be useful. I started to collaborate, working with a friend before exam time. As I progressed through the course and my clinical skills developed I became more confident and more able to try different approaches to learning. I will admit that I remain competitive not least around exam times and was rewarded with an undergraduate prize.

Postgraduate training has changed my attitudes and approach further. I am much more self-directed. I found the apprenticeship model of being a GP registrar very helpful, I was introduced to the concept of reflective practice ${ }^{9}$ and started to keep a learning journal. My trainer helped me to become autonomous ${ }^{10}$ and encouraged me to develop for myself a 'curriculum customised to [my] prior knowledge'. ${ }^{8}$ I found it enlightening to be learning in context and to set my own goals. I started to work in a study group for the MRCGP and I still meet with the group for ongoing CPD. I still find some subjects difficult to engage with or to take an interest in but I find the PUN/DEN approach helpful to guide my work and to help me continue to practice reflectively.

As a educator I am conscious that there are a wide variety of different styles of teaching each of which has its place. I try to be adaptable in my approach, ${ }^{11}$ however I try hard not to match my teaching style to the students' preferred style every time, not least because I am aware that some mismatch will promote deeper understanding..$^{12}$ I am very conscious that it took me a long time to develop as an adult learner. I try to introduce the students to the concept of reflective practice. In one of the modules I teach at Sheffield University each tutorial begins with a significant-event analysis where I try to get them to work through Kolb and Fry's Learning Cycle ${ }^{13}$ and we also talk about Schon's ${ }^{9}$ concepts of 'reflection in action' and 'reflection on action' and I introduce the ideas of PUNs and DENs.

I mainly teach small groups in a seminar style setting. I tend to use different approaches in one-to-one teaching. Sometimes when I have someone sat in my surgery with me (for example, a nurse or registrar) I will use a 'mini-lecture' as a quick method of delivering information appropriate to the immediate setting. I 
remember being irritated by tutors telling me to 'go home and read about it yourself' and so I try to support my students while still trying to encourage them to be self directed.

I accept that just before examinations students will often switch to a surface approach $^{6}$ in their learning, I try to encourage students to take a deep approach and to understand what they are doing and to try to work from principles. I do think that reward often stimulates learning; the reward can vary from student to student whether it is passing an exam, getting a job or simply learning for one's own enjoyment. I am conscious that I have always been very competitive and I make great efforts to ensure that I do not stray too far into a Socratic method ${ }^{11}$ and risk humiliating my students.

\section{Tara George}

\section{REFERENCES}

1. Cantillon P, Wood D, Hutchinson L. ABC of learning and teaching in medicine. London: BMJ Publishing Group, 2003.

2. Grasha A. Teaching with style: a practical guide to enhancing learning by understanding learning and teaching styles. New York, NY: Alliance Publishers, 1996.

3. Phillips DC and Soltis JF. Perspectives on learning. New York: Teachers College Press, 1985.

4. Montauk S and Grasha A. Adult HIV outpatient care: A handbook for clinical teaching. Cincinnati, $\mathrm{OH}$ : University Of Cincinnati, 1993.

5. Bandura A. Social foundations of thought and action: a social cognitive theory. Englewood Cliffs, NJ: Prentice Hall, 1986.

6. Biggs J. Handbook of educational ideas and practices. London and New York, NY: Routledge, 1990.

7. Knowles MS. Andragogy in action: applying modern principles of adult learning. San Francisco, CA: JosseyBass, 1984.

8. Hirsch ED. The knowledge core curriculum — what's behind its success? Educational Leadership 1993; 50(8): 23-25.

9. Schon DA. Educating the reflective practitioner: towards a new design for teaching and learning in the profession. San Francisco, CA: Jossey-Bass, 1987.

10. Boud D. Developing student autonomy in learning. London: Kogan Page, 1988.

11. Vaughn L, Baker R. Teaching in the medical setting: balancing teaching styles, learning styles and teaching methods. Medical Teacher 2001; 23(6): 610-612.

12. Dember W. The new look in motivation. American Scientist 1965; 53, 409-427.

13. Kolb DA, Fry R. Towards an applied theory of experiential learning. In: Cooper LD (ed). Theories of Group Processes. London: John Wiley, 1975.

DOI: 10.3399/bjgp09X472999

\section{Maike Fitzpatrick}

\section{Diagnostic delusions}

One of the few bright moments for Labour politicians slouching grimly towards electoral doom at this year's party conference was the announcement that GPs will soon be able to refer suspected cancer patients for key diagnostic tests within 1 week. This initiative was applauded by delegates, acclaimed by the Guardian ('could save up to 10000 lives a year') and welcomed by cancer charities. The president of the Royal College of General Practitioners hailed it 'one of the most important breakthroughs' for GPs, claiming that it represented 'a major vote of confidence in the ability and professionalism of GPs who for too long have been dismissed as the poor relations of our specialist colleagues'.?

But does early diagnosis confer a better prognosis? According to the National Awareness and Early Diagnosis Initiative (NAEDI), 'we have known for years that, in general, the earlier cancer is diagnosed and treated, the greater are the chances of a successful outcome'. ${ }^{3}$ However, we soon learn that we 'know' this in the same way that generations of doctors 'knew' that bleeding and cupping and purging were effective therapies. 'With the exception of breast cancer', the promoters of the early diagnosis initiative admit, 'there is no solid evidence for the actual effect of delay on survival in cancer'.

But who needs 'solid' evidence of an 'actual' effect when the power of wishful thinking can unite desperate politicians and credulous journalists, medical entrepreneurs, and a fearful public? Another NAEDI bulletin reports how the headline figures of preventable deaths are derived. 'Drawing on processes of elimination and extrapolation', (the magic of statistics!), Mike Richards (the government's cancer 'Tsar') 'presented his personal view that advanced stage at diagnosis is likely to account for at least $50-75 \%$ of avoidable cancer deaths'. ${ }^{4}$ 'Likely'? 'At least'? '50-75\%'? Why not $100 \%$ - or $0 \%$ ? But we mustn't be pernickety because 'this equates to something like 4000-7500 unnecessary deaths each year'. Yet it seems that a few earlier scans arranged by GPs can save 10000 lives - even more than are being 'unnecessarily' lost. We seem to have entered 'something like' a parallel universe.

Professor Richards may be right that some cancer patients would live for longer if they were diagnosed earlier. But the personal conviction of even such a distinguished oncologist cannot be regarded as a satisfactory basis for a major national programme. It is not only that the benefits of such an initiative need to be demonstrated, but the potential harms should also be recognised.

Although the NAEDI bulletin claims that, exceptionally, there is some evidence for the benefit of early diagnosis of breast cancer, there is also evidence of the adverse effects of mammographic screening (particularly in terms of overdiagnosis and overtreatment). ${ }^{5}$ There is controversy only over the proportion of women who experience unnecessary surgery, radiotherapy, and chemotherapy as a result of mammography (and the number is certain to be increased as a result of another popular announcement at Brighton - Gordon Brown's promise to reduce the age of eligibility for breast screening).

The notion that GPs will be 'empowered' by being enabled to order investigations is illusory. We are already becoming mere agents endorsing demands for recreational screening tests. Nor can the problem for the public be reduced to that of the 'worried well'. The quest for early diagnosis inexorably transforms every citizen into a potential patient. This will not improve health, still less enable people to achieve that even more elusive goal of government policy, 'wellbeing'.

\section{REFERENCES}

1. Stratton A. Gordon Brown to woo conference with cancer pledge and new NHS cash. Guardian, 2009; 26 Sep:

http://www.guardian.co.uk/politics/2009/sep/26/gord on-brown-conference-cancer-nhs (accessed 6 Oct 2009).

2. Ellis O. GPs are to refer suspected cancer patients for tests in a week under new scheme. BMJ 2009; 339: b3994.

3. Forman D, Sara Hiom. Review of the evidence base. National Awareness and Early Diagnosis Initiative, Newsletter 2008; 1(1): 3 .

4. Anonymous. Keynote Speech: 'The Size of the Prize' National Awareness and Early Diagnosis Initiative, Newsletter 2008; 2(1): 3 .

5. Fitzpatrick M. Sense about mammography. Br J Gen Pract 2009; 59(561): 297.

DOI: 10.3399/bjgp09X473006 